\title{
Phosphorylation of p27(KIP1) in lens epithelial cells after extraction of fiber cells
}

\author{
SATORU KASE ${ }^{1}$, KAZUHIKO YOSHIDA ${ }^{1}$, XUE-HAI JIN ${ }^{1}$, YOSHIKAZU KOYAMA ${ }^{2}$, NOBUYOSHI KITAICHI ${ }^{1}$, \\ KAZUHIRO OHGAMI $^{1}$, KENJI SHIRATORI ${ }^{1}$, ILIYANA ILIEVA ${ }^{1}$ and SHIGEAKI OHNO ${ }^{1}$ \\ Departments of ${ }^{1}$ Ophthalmology and Visual Sciences and ${ }^{2}$ Biochemistry, \\ Hokkaido University Graduate School of Medicine, N15 W7, Kita-ku, Sapporo 060-8638, Japan
}

Received June 7, 2006; Accepted August 3, 2006

\begin{abstract}
Opacification of the posterior capsule depends on replication of the residual lens epithelial cells lining the capsule. However, the mechanisms in the regulation of lens cell proliferation have not been determined. The purpose of this study is to examine the expression of p27(KIP1), a cyclindependent kinase inhibitor, and its phosphorylation, and cyclin D1 in lens epithelial cells after extraction of fiber cells. C57B16 mice (12 weeks old) were anesthetized, and the lens fiber cells were surgically extracted. Eyeballs were collected and fixed at $15 \mathrm{~min}$ and $24 \mathrm{~h}$ after extraction with and without injection of a specific phosphorylated extracellular signal-regulated kinase (pERK) 1/2 inhibitor (PD98059) to the anterior chamber. Collected tissues were analyzed using immunohistochemistry with anti-p27(KIP1), anti-phosphorylated p27(KIP1) on serine 10 (s10-phospho-p27) and cyclin D1 antibodies. Human lens epithelial cells were cultured, and then were treated with and without $40 \mathrm{ng} / \mathrm{ml}$ human recombinant basic fibroblast growth factor (bFGF), which was analyzed by Western blot analysis. In the untreated lens, p27(KIP1) was not phosphorylated in the lens epithelial cells, although p27(KIP1)-positive nuclei were detected in the lens cells of the equatorial region. Immunoreactivity for cyclin D1 was hardly detected in the lens. Nuclear immunoreactivity for p27(KIP1) and s10-phospho-p27 was observed in several lens cells of the equatorial region $15 \mathrm{~min}$ after extraction of fiber cells. Western blotting demonstrated that the p27(KIP1) phosphorylation form was upregulated $15 \mathrm{~min}$ after bFGF treatment in cultured lens epithelial cells. Many cyclin D1-positive nuclei were noted $24 \mathrm{~h}$ after the surgery. p27(KIP1) phosphorylation and cyclin D1 induction were inhibited by PD98059. s10-phospho-p27 and p27(KIP1) immunoreactivity was undetected in the lens cells $24 \mathrm{~h}$ after
\end{abstract}

Correspondence to: Dr Satoru Kase, Department of Ophthalmology and Visual Sciences, Hokkaido University Graduate School of Medicine, N15 W7, Kita-ku, Sapporo 060-8638, Japan

E-mail: kaseron@med.hokudai.ac.jp

Key words: p27(KIP1), phosphorylation, lens, extraction the extraction of fiber cells. It is possible that the phosphorylation of $\mathrm{p} 27(\mathrm{KIP} 1)$, and cyclin D1 expression are regulated by the ERK pathway in lens cells after the extraction of fiber cells.

\section{Introduction}

Lens epithelial cells at the equatorial region continue proliferating and differentiating throughout life. The exquisitely regulated program of cell division, withdrawal from the cell cycle and differentiation into fibers is essential for lens formation and lens transparency (1). Improper proliferation of lens epithelial cells after cataract surgery is causally related to posterior capsule opacification (PCO) $(2,3)$. However, the mechanisms in the regulation of lens cell proliferation are still unclear.

Cell cycle progression is controlled by a series of kinase complexes composed of cyclins and cyclin-dependent kinases (CDKs) (4). The enzymatic activities of cyclin/CDK complexes are regulated by many mechanisms that reflect both the diversity of the signals they integrate, and the central importance of their roles in cell cycle control. Cyclin D1 is one of the G1 cyclins, and is rapidly induced upon exposure of cells to mitogens (5). On the other hand, the regulatory mechanisms include the actions of CDK inhibitors (CKIs) such as p27(KIP1) and p57(KIP2) $(6,7)$. The elimination of p27(KIP1) during the late G1 phase is required for cell cycle progression from the $\mathrm{G} 1$ to the $\mathrm{S}$ phase in various cell lines (8-11). We have demonstrated that p27(KIP1) is involved in proliferation of cells in the retina, retinal pigment epithelium, the ciliary body and the cornea (12-22). We recently reported that immunoreactivity for p27(KIP1), but not p57(KIP2), was detected in murine adult lens epithelial cells (23).

Previous studies indicated that posttranslational mechanisms regulated the expression level of p27(KIP1) protein (24-26). The ubiquitin-mediated proteasome pathway was suggested to be involved in p27(KIP1) degradation in mammals (25). The regulation of ubiquitin-mediated proteolysis is often achieved by phosphorylation of the target protein, which renders it more susceptible to degradation. It is reported that phosphorylation of $\mathrm{p} 27$ (KIP1) on serine 10 induces p27(KIP1) degradation (27), which can be regulated through the phosphorylation of extracellular signal-regulated kinase 
(pERK) 1/2 (17,28,29). Proteasome-dependent degradation of p27(KIP1) was associated with the G1/S phase transition in human lens epithelial cells (1). We recently demonstrated that degradation of $\mathrm{p} 27(\mathrm{KIP} 1)$ led to the proliferation of retinal glial cells in vivo, which was suppressed by using pERK 1/2 inhibitor (17).

In this study, we examined the phosphorylation of p27(KIP1), and cyclin D1 expression in lens epithelial cells after extraction of fiber cells. Moreover, the expression of other cell cycle-related molecules such as p21WAF1, cyclin $\mathrm{E}, \mathrm{p} 15$, and $\mathrm{p} 16$, which is correlated with the regulation of G1/S phase transition was examined in murine lens epithelial cells $(1,30)$.

\section{Materials and methods}

Animals and tissues. All animal experiments conformed to the ARVO Resolution on the Use of Animals in Research. C57B16 mice were obtained from Hokudo Co. Ltd., Sapporo, Japan. Before the extraction of the lens nuclei, 12-week-old mice were anesthetized with an intraperitoneal injection of sodium pentobarbital after topical anesthesia with $0.4 \%$ oxybuprocaine. The limbal regions of the corneas and the equatorial regions of the lenses in the mouse eyes were excised using a razor blade (cat no. FA-10, Feather, Osaka, Japan). Then the lens fiber cells were extracted by pushing the limbus from the opposite side. The corneas were sutured with 11-0 nylon at the end of the surgery. After the surgery, ofloxacin ointment was applied to the eyes to avoid infection. The eyes showed no signs of infection when observed with a dissection microscope. Ten eyes were obtained from each group at $15 \mathrm{~min}$ and $24 \mathrm{~h}$ after the surgery, along with untreated eyes. Finally, they were fixed transcardially with $4 \%$ paraformaldehyde in $0.1 \mathrm{M}$ borate buffer $(\mathrm{pH} 9.5)$ for $2 \mathrm{~h}$ and processed to prepare 10 -mm-thick paraffin sections.

The mice were injected with $50 \mu$ mol PD98095, a specific ERK 1/2 inhibitor (31), into the anterior chamber just after the surgery, by introducing a $30 \mathrm{G}$ needle between the sutures. The eyes were dissected $15 \mathrm{~min}$ or $24 \mathrm{~h}$ after the injection, and they were prepared for paraffin sectioning.

Immunohistochemistry. The slides were dewaxed, rehydrated, and rinsed in phosphate-buffered saline (PBS) twice and incubated with normal goat serum and then with the antip27(KIP1) antibody (dilution 1:100; Transduction Laboratories, Lexington, KY), anti-serine 10 phosphorylated p27(KIP1) (s10-phospho-p27) antibody (1:100), anti-cyclin D1 antibody (1:200), anti-p21 antibody (1:100), anti-cyclin E antibody (1:100), anti-p15 antibody (1:100), and anti-p16 antibody (1:100) (all from Santa Cruz Biotechnology, Santa Cruz, CA). Binding of the primary antisera was localized using FITC-conjugated goat anti-mouse IgG, donkey anti-goat IgG or goat anti-rabbit IgG (dilution 1:200; Jackson ImmunoResearch Laboratories Inc., West Grove, PA). For the negative control in each staining, serial sections without incubation with the primary antibody were incubated with the FITC-conjugated goat anti-mouse IgG. Nuclei were then stained with PBS containing 4'6-diamidino-2-phenylindole (DAPI) for $5 \mathrm{~min}$. The slides were examined by laser scanning confocal microscopy (MRC-1024; Bio-Rad,

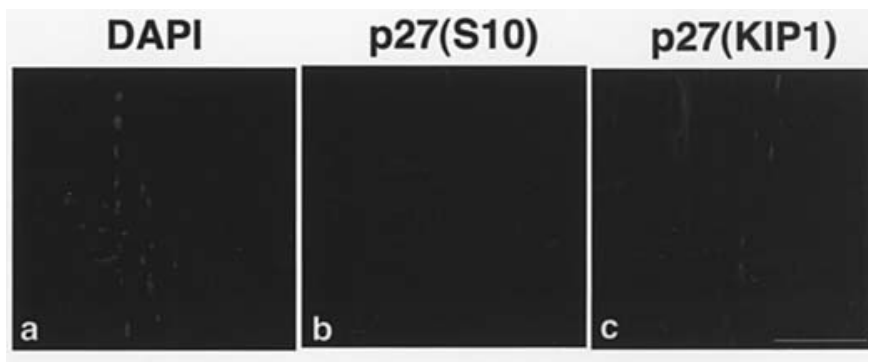

Figure 1. Untreated lens. DAPI nuclear staining (a) and immunodetection of serine 10 phosphorylated p27(KIP1) (p27(S10)) (b) and p27(KIP1) (c) in the normal lenses of C57B16 adult mice. Phosphorylation of p27(KIP) is not observed in lens epithelial cells (b). Nuclear immunoreactivity of p27(KIP1) is detected in many lens cells of the equatorial region (c). Bar indicates $30 \mathrm{um}$.

Richmond, CA; and LSM 510; Carl Zeiss, Oberkochen, Germany).

Cell culture of human lens epithelial cells. Human lens epithelial cells (B-3) transformed with an adenovirus 12SV40 virus hybrid (Ad12-SV40) (32) were purchased. The cells were cultured with Dulbecco's modified Eagle's medium plus $10 \%$ fetal calf serum, which were incubated in a $95 \%$ air $/ 5 \% \mathrm{CO}_{2}$ atmosphere with a humidity of $37 \%$. The cells were routinely passaged every week upon reaching confluency, and the medium was renewed every. The cells were grown at $1 \times 10^{5}$ cells per well in $10 \mathrm{~cm}$ dishes in $10 \mathrm{ml}$ complete medium until $\sim 80 \%$ confluency was reached. At this stage, the medium was discarded and replaced with $10 \mathrm{ml}$ control medium, and $40 \mathrm{ng} / \mathrm{ml}$ recombinant human basic fibroblast growth factor (bFGF) (R\&D Systems, cat. no. 233-FB) was added. The medium was removed $15 \mathrm{~min}$ after the treatment, the cells were washed twice with cold phosphate-buffered saline ( $\mathrm{pH} 7.4$; Invitrogen), and the monolayer was scraped into $200 \mu 1$ of lysis buffer (mammalian cell lysis-1 kit, Sigma).

Western blot analysis. The total cell lysates were centrifuged at $10,000 \mathrm{x} \mathrm{g}$ for $10 \mathrm{~min}$, and the supernatant was analyzed by Western blotting. Equal amounts of protein $(30 \mu \mathrm{g})$ were separated by $10 \%$ SDS-polyacrylamide gel electrophoresis. Immunoblots were probed with primary antibodies against p27(KIP1) (dilution 1:1000; Transduction Laboratories), s10-phospho-p27 (1:1000; Santa Cruz Biotechnology), and $\alpha$-tubulin (1:3000; Lab Vision, Fremont, CA), and then with secondary antibodies at $4^{\circ} \mathrm{C}$ overnight. Immunoreactive bands were visualized using an enhanced chemiluminescence system (ECL detection system; Amersham Pharmacia Biotech, Buckinghamshire, UK).

\section{Results}

In the untreated lens, p27(KIP1) was not phosphorylated in the lens epithelial cells (Fig. 1a and b), although p27(KIP1)positive nuclei were detected in the lens cells of the equatorial region (Fig. 1c). In contrast, $\mathrm{CDK}$ inhibitors, p15, p16 and p21WAF1, were not expressed in the lens epithelial nuclei (data not shown). Therefore, we focused on the phosphorylation of p27(KIP1) in the lens cells after fiber cell extraction. Nuclear immunoreactivity for s10-phospho-p27 


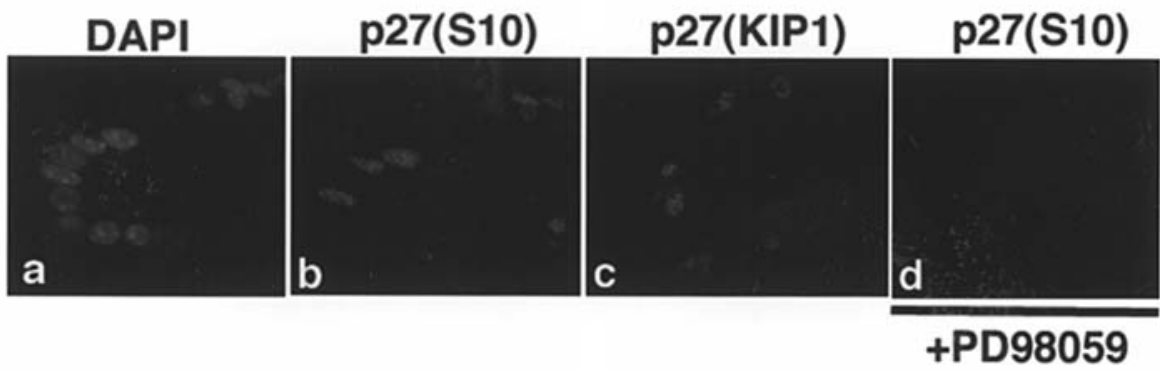

Figure 2. Surgically extracted lens fiber cells (15 min after surgery). DAPI nuclear staining (a), immunodetection of serine 10 phosphorylated p27(KIP1) (s10phospho-p27) (b), and p27(KIP1) (c) 15 min after the extraction of lens fiber cells. Nuclear immunoreactivity for s10-phospho-p27 is observed in several lens cells of the equatorial region (b). p27(KIP1)-positive nuclei are detected in the lens cells (c). Immunoreactivity for s10-phospho-p27 in the lens cells after the extraction with injection of a selective phosphorylated extracellular signal-regulated kinase $1 / 2$ inhibitor, PD98059, into the anterior chamber (d). Specific immunoreaction of s10-phospho-p27 is not observed (d). p27(S10), s10-phospho-p27; bar indicates 30 um.

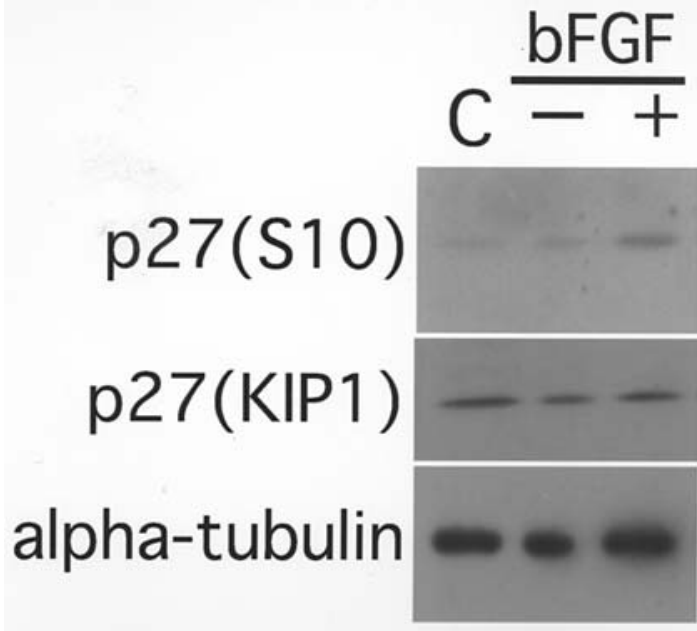

Figure 3. Phosphorylation of p27(KIP1) on serine 10 [p27(S10)], p27(KIP1) and $\alpha$-tubulin in human cultured lens epithelial cells 15 min after treatment with basic fibroblast growth factor (bFGF). Left lane: untreated lens epithelial cells. Lens cells treated with solution containing no bFGF (middle), as well as with bFGF (right) are shown. Upper lane: s10-phospho-p27 is noted in lens cells $15 \mathrm{~min}$ after bFGF treatment. Middle and lower lanes: whole p27(KIP1) (middle) and $\alpha$-tubulin expression show no remarkable change in lens cells with and without treatment. p27(S10), phosphorylation of p27(KIP1) on serine 10; C, control.

was observed in several lens cells of the equatorial region 15 min after extraction of fiber cells (Fig. 2a and b). p27(KIP1)-positive nuclei were also detected in the lens cells after the extraction (Fig. 2c). We have already demonstrated that nuclear immunoreactivity for pERK $1 / 2$ was detected in the equatorial region $15 \mathrm{~min}$ after lens extraction (23). In this study, phosphorylation of p27(KIP1) on serine 10 was completely inhibited in the lens cells after the extraction with PD98059 treatment (Fig. 2d). Moreover, s10-phospho-p27 or p27(KIP1) immunoreactivity was not detected in the lens cells $24 \mathrm{~h}$ after the extraction of fiber cells without the treatment (data not shown). We examined 10 animals 15 min and $24 \mathrm{~h}$ after the extraction and observed these changes reproducibly.

It is reported that bFGF plays a role in PCO formation by promoting the survival of abnormal cells with PCO-like characteristics (33). In order to elucidate the phosphorylation of p27(KIP1) in lens cells after fiber cell extraction, cultured
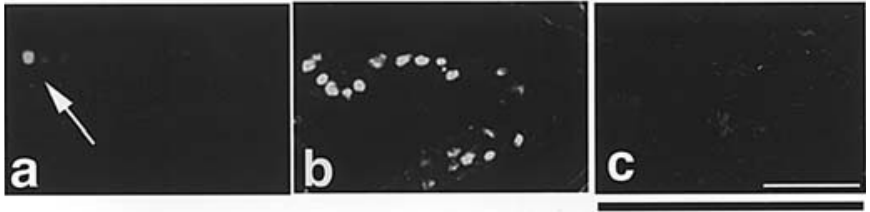

+PD98059

Figure 4. Expression of cyclin D1 in lens cells of the equatorial region in untreated (a) and surgically fiber cell-extracted (b and c) eyes. In untreated mice, cyclin D1 is expressed in the nucleus of only a few lens epithelial cells in the equatorial region (a, arrow). Many cyclin D1-positive nuclei are noted in the lens cells of the equatorial region $24 \mathrm{~h}$ after fiber cell extraction (b). Cyclin D1-positive lens cells are not observed in the equatorial region by using a selective phosphorylated extracellular signal-regulated kinase 1/2 inhibitor, PD98059 (c). Bar indicates 30 um.

human lens epithelial cells were treated with human recombinant bFGF and were examined using Western blot analysis. The p27(KIP1) phosphorylation form was upregulated in lens cells $15 \mathrm{~min}$ after treatment with $40 \mathrm{ng} / \mathrm{ml} \mathrm{bFGF}$ (Fig. 3, upper lane). In contrast, alteration of protein levels of whole p27(KIP1) (Fig. 3, middle lane) and $\alpha$-tubulin (Fig. 3, lower lane) were not apparent.

Cyclin D1 was expressed in a few lens epithelial cells of the equatorial region (Fig. 4a) in untreated mice, as well as 15 min after fiber cell extraction, whereas immunoreactivity for cyclin $\mathrm{E}$ was not detected in lens cells (data not shown). In contrast, many cyclin D1-positive nuclei were noted in the lens cells $24 \mathrm{~h}$ after fiber cell extraction (Fig. 4b). Furthermore, the expression was completely blocked by using PD98059 (Fig. 4c).

\section{Discussion}

Degradation of $\mathrm{p} 27(\mathrm{KIP} 1)$ is required for the cellular transition from quiescence to the proliferative state $(6,7,24,34)$. In this study, we demonstrated that p27(KIP1)-positive nuclei were detected in lens epithelial cells without extraction and $15 \mathrm{~min}$ after the extraction of fiber cells. In contrast, expression of p27(KIP1) was not observed $24 \mathrm{~h}$ after the extraction. Lens cells in the equatorial region have been suggested to show the cellular transition from quiescence to the proliferative state by disappearance of p27(KIP1) after the extraction of fiber cells $(6,7,24,34)$. 
It has been reported that phosphorylation of p27(KIP1) on serine 10 induces p27(KIP1) degradation (27). In this study, p27(KIP1) was phosphorylated on serine 10 in lens epithelial cells of the equatorial region 15 min after the extraction of fiber cells. Immunoreactivity for serine 10-phosphorylated p27(KIP1) in the lens cells disappeared $24 \mathrm{~h}$ after the extraction, when p27(KIP1)-positive nuclei were not observed. This phosphorylation event is involved in the disappearance of p27(KIP1) in lens cells, as reported in choroidal melanoma cells (29).

bFGF is a pleiotropic protein, and it promotes proliferation and migration of lens epithelial cells, as well as differentiation into fiber cells (35). Therefore, FGF plays a role in PCO formation by promoting the survival of abnormal cells with PCO-like characteristics (33). In this study, we also demonstrated that phosphorylation of p27(KIP1), but not of whole p27(KIP1), was upregulated in cultured human lens epithelial cells 15 min after treatment with bFGF. These data suggest that p27(KIP1) phosphorylation is correlated with an early event of pathogenesis in PCO in vivo and in vitro.

Phosphorylation of $\mathrm{p} 27$ (KIP1) on serine 10 can be regulated through pERK $1 / 2(17,28,29)$. We recently demonstrated that $\mathrm{p} 27(\mathrm{KIP} 1)$ disappeared and the proliferation activity was induced in the lens cells after fiber cell extraction, which was inhibited by PD98059 (23), suggesting that a phosphorylation event might be involved by pERK in the degradation of p27(KIP1). In this study, immunoreactivity for s10-phospho-p27 was completely inhibited in the lens cells after the extraction with PD98059 treatment. Collectively, it is possible that phosphorylation of $\mathrm{p} 27(\mathrm{KIP} 1)$ is regulated by the ERK pathway.

ERK functions as an upstream activator of transcription from the cyclin D1 promoter (36), and the expression of cyclin D1 is involved in the cellular transition from quiescence to the proliferative state (5). We confirmed that cyclin D1 was hardly detected in the normal adult lens, and that it was induced in the lens cells $24 \mathrm{~h}$ after fiber cell extraction. This induction was inhibited by treatment of the mice with PD98059 (Fig. 4). These findings indicate that ERK plays an important role in the regulation of cyclin D1 expression as well as p27(KIP1) phosphorylation in lens epithelial cells after extraction of fiber cells.

Opacification of the posterior capsule is also called 'after cataract' and depends on the replication of residual epithelial cells lining the capsule (3). Today, ophthalmologists routinely perform a laser capsulotomy to treat postoperative capsular opacification. Although the technique is widely accepted, it sometimes causes complications such as damage to the intraocular lens (IOL), cystoid macular edema, elevated intraocular pressure, or IOL dislocation. Thus, preventing opacification would be a better, less expensive and safer treatment for cataracts. Targeting such early signaling and transcriptional events with pharmaceutical intervention after extraction of fiber cells in humans may help to reduce downstream cellular effects such as proliferation after surgical correction. Identification of the mechanism that regulates the protein levels of p27(KIP1) and its phosphorylation should prove valuable in delineating the molecular pathways underlying posterior capsular opacity, which involves the proliferation of lens epithelial cells (3).

\section{Acknowledgements}

This study was supported by a grant for Research on Sensory and Communicative Disorders from The Ministry of Health, Labor, and Welfare, and by Grants-in-Aid for Scientific Research from The Ministry of Education, Culture, Sports, Science, and Technology (MEXT), Japan.

\section{References}

1. Liu Q, Shang F, Guo W, Hobbs M, Valverde P, Reddy V and Taylor A: Regulation of the ubiquitin proteasome pathway in human lens epithelial cells during the cell cycle. Exp Eye Res 78: 197-205, 2004.

2. Marcantonio JM, Rakic JM, Vrensen GF and Duncan G: Lens cell populations studied in human donor capsular bags with implanted intraocular lenses. Invest Ophthalmol Vis Sci 41: 1130-1141, 2000.

3. Ursell PG, Spalton DJ, Pande MV, Hollick EJ, Barman S, Boyce $\mathrm{J}$ and Tilling K: Relationship between intraocular lens biomaterials and posterior capsule opacification. J Cataract Refract Surg 24: 352-360, 1998.

4. Sherr CJ and Roberts JM: Inhibitors of mammalian G1 cyclindependent kinases. Genes Dev 9: 1149-1163, 1995.

5. Sherr CJ: G1 phase progression: cycling on cue. Cell 79: 551-555, 1994.

6. Toyoshima $\mathrm{H}$ and Hunter T: p27, a novel inhibitor of G1 cyclinCdk protein kinase activity, is related to p21. Cell 78: 67-74, 1994.

7. Kato JY, Matsuoka M, Polyak K, Massague J and Sherr CJ: Cyclic AMP-induced G1 phase arrest mediated by an inhibitor (p27Kip1) of cyclin-dependent kinase 4 activation. Cell 79: 487-496, 1994.

8. Nourse J, Firpo E, Flanagan WM, Coats S, Polyak K, Lee MH, Massague J, Crabtree GR and Roberts JM: Interleukin-2mediated elimination of the p27Kip1 cyclin-dependent kinase inhibitor prevented by rapamycin. Nature 372: 570-573, 1994.

9. Reynisdottir I, Polyak K, Iavarone A and Massague J: Kip/Cip and Ink4 Cdk inhibitors cooperate to induce cell cycle arrest in response to TGF-beta. Genes Dev 9: 1831-1845, 1995.

10. Coats S, Flanagan WM, Nourse J and Roberts JM: Requirement of p27Kip1 for restriction point control of the fibroblast cell cycle. Science 272: 877-880, 1996

11. Hirai A, Nakamura S, Noguchi Y, Yasuda T, Kitagawa M, Tatsuno I, Oeda T, Tahara K, Terano T, Narumiya S, Kohn LD and Saito Y: Geranylgeranylated rho small GTPase(s) are essential for the degradation of p27Kip1 and facilitate the progression from G1 to $\mathrm{S}$ phase in growth-stimulated rat FRTL5 cells. J Biol Chem 272: 13-16, 1997.

12. Nakayama $K$, Ishida $N$, Shirane $M$, Inomata $A$, Inoue $T$, Shishido N, Horii I and Loh DY: Mice lacking p27(Kip1) display increased body size, multiple organ hyperplasia, retinal dysplasia, and pituitary tumors. Cell 85: 707-720, 1996.

13. Yoshida K, Nakayama K, Nagahama H, Harada T, Harada C, Imaki J, Matsuda A, Yamamoto K, Ito M, Ohno S and Nakayama KI: Involvement of p27(KIP1) degradation by Skp2 in the regulation of proliferation in response to wounding of corneal epithelium. Invest Ophthalmol Vis Sci 43: 364-370, 2002.

14. Yoshida K, Nakayama K, Kase S, Nagahama H, Harada T, Ikeda H, Harada C, Imaki J, Ohgami K, Shiratori K, Ohno S, Nishi S and Nakayama KI: Involvement of p27(KIP1) in proliferation of the retinal pigment epithelium and ciliary body. Anat Embryol (Berl) 208: 145-150, 2004.

15. Yoshida K, Kase S, Nakayama K, Nagahama H, Harada T, Ikeda H, Harada C, Imaki J, Ohgami K, Shiratori K, Ilieva IB, Ohno S, Nishi S and Nakayama KI: Involvement of p27KIP1 in the proliferation of the developing corneal endothelium. Invest Ophthalmol Vis Sci 45: 2163-2167, 2004.

16. Yoshida K, Kase S, Nakayama K, Nagahama H, Harada T, Ikeda H, Harada C, Imaki J, Ohgami K, Shiratori K, Ohno S and Nakayama KI: Distribution of p27(KIP1), cyclin D1, and proliferating cell nuclear antigen after retinal detachment. Graefes Arch Clin Exp Ophthalmol 242: 437-441, 2004.

17. Kase S, Yoshida K, Harada T, Harada C, Namekata K, Suzuki Y, Ohgami K, Shiratori K, Nakayama KI and Ohno S: Phosphorylation of extracellular signal-regulated kinase and p27(KIP1) after retinal detachment. Graefes Arch Clin Exp Ophthalmol 244: 352-358, 2006. 
18. Kase S, Yoshida K, Nakayama KI, Nakayama K, Ikeda H, Harada T, Harada C, Ohgami K, Shiratori K and Ohno S: Phosphorylation of p27(KIP1) in the developing retina and retinoblastoma. Int J Mol Med 16: 257-262, 2005.

19. Kase S, Saito W, Yokoi M, Yoshida K, Furudate N, Muramatsu M, Saito A, Kase M and Ohno S: Expression of glutamine synthetase and cell proliferation in human idiopathic epiretinal membrane. Br J Ophthalmol 90: 96-98, 2006.

20. Kase S, Yoshida K, Ohgami K, Shiratori K, Harada T and Ohno S: Expression of p27(KIP1) and cell proliferation in human retina and retinoblastoma. Anticancer Res 25: 3843-3846, 2005

21. Kase S, Yoshida K, Ohgami K, Shiratori K, Suzuki Y, Nakayama KI and Ohno S: Expression of cde2 and p27(KIP1) phosphorylation in mitotic cells of the human retinoblastoma. Int J Mol Med 17: 465-468, 2006.

22. Kase S, Yoshida K, Ohgami K, Shiratori K, Ohno S and Nakayama K: Phosphorylation of p27(KIP1) in the mitotic cells of the corneal epithelium. Curr Eye Res 31: 307-312, 2006.

23. Kase S, Yoshida K, Ikeda H, Harada T, Harada C, Imaki J, Ohgami K, Shiratori K, Nakayama KI, Nakayama K and Ohno S: Disappearance of $\mathrm{p} 27(\mathrm{KIP} 1)$ and increase in proliferation of the lens cells after extraction of most of the fiber cells of the lens. Curr Eye Res 30: 437-442, 2005.

24. Polyak K, Lee MH, Erdjument-Bromage H, Koff A, Roberts JM, Tempst $\mathrm{P}$ and Massague $\mathrm{J}$ : Cloning of p27Kip1, a cyclindependent kinase inhibitor and a potential mediator of extracellular antimitogenic signals. Cell 78: 59-66, 1994.

25. Pagano M, Tam SW, Theodoras AM, Beer-Romero P, Del Sal G, Chau V, Yew PR, Draetta GF and Rolfe M: Role of the ubiquitin-proteasome pathway in regulating abundance of the cyclin-dependent kinase inhibitor p27. Science 269: 682-685, 1995.

26. Hengst L and Reed SI: Translational control of p27Kip1 accumulation during the cell cycle. Science 271: 1861-1864, 1996.

27. Ishida N, Kitagawa M, Hatakeyama $S$ and Nakayama K: Phosphorylation at serine 10 , a major phosphorylation site of p27Kip1, increases its protein stability. J Biol Chem 275: 25146-25154, 2000.
28. Foster JS, Fernando IR, Ishida N, Nakayama KI and Wimalasena J: Estrogens down-regulate p27Kip1 in breast cancer cells through SKP2, and through nuclear export mediated by the extracellular signal-regulated kinase (Erk) pathway. J Biol Chem 17: 41355-41366, 2003.

29. Delmas C, Aragou N, Poussard S, Cottin P, Darbon JM and Manenti S: MAP kinase-dependent degradation of p27Kip1 by calpains in choroidal melanoma cells. Requirement of p27Kip1 nuclear export. J Biol Chem 278: 12443-12451, 2003.

30. Guo W, Shang F, Liu Q, Urim L, West-Mays J and Taylor A: Differential regulation of components of the ubiquitinproteasome pathway during lens cell differentiation. Invest Ophthalmol Vis Sci 45: 1194-1201, 2004.

31. Di Girolamo N, Coroneo MT and Wakefield D: UVB-elicited induction of MMP-1 expression in human ocular surface epithelial cells is mediated through the ERK1/2 MAPKdependent pathway. Invest Ophthalmol Vis Sci 44: 4705-4714, 2003.

32. Andley UP, Rhim JS, Chylack Jr LT and Fleming TP: Propagation and immortalization of human lens epithelial cells in culture. Invest Ophthalmol Vis Sci 35: 3094-3102, 1994.

33. Mansfield KJ, Cerra A and Chamberlain CG: FGF-2 counteracts loss of TGFbeta affected cells from rat lens explants: implications for PCO (after cataract). Mol Vis 10: 521-532, 2004.

34. Harper JW and Elledge SJ: Cdk inhibitors in development and cancer. Curr Opin Genet Dev 6: 56-64, 1996.

35. Ibaraki N, Lin LR and Reddy VN: Effects of growth factors on proliferation and differentiation in human lens epithelial cells in early subculture. Invest Ophthalmol Vis Sci 36: 2304-2312, 1995.

36. Ramakrishnan MN, Li J, Liu PT, Pestell RG and Hershenson MB: Catalytic activation of extracellular signal-regulated kinases induces cyclin D1 expression in primary tracheal myocytes. Am J Respir Cell Mol Biol 18: 736-740, 1998. 